Diego Giulliano Destro Christofaro ${ }^{1}$

Rômulo Araújo Fernandes ${ }^{1}$

Catarina Martins ${ }^{2}$

Enio Ricardo Vaz Ronque ${ }^{3}$

Manuel João Coelho-e-Silva ${ }^{4}$

Analiza Mônica Silva ${ }^{5}$

Luis Bettencourt Sardinha ${ }^{5}$

Edilson Serpeloni Cyrino ${ }^{3}$

${ }^{1}$ Faculdade de Educação Física, Universidade Estadual Paulista Júlio de Mesquita Filho. Vila Santa Helena. 19060-900 Presidente Prudente SP Brasil. diegochristofaro@ yahoo.com.br

${ }^{2}$ Faculdade de Motricidade Humana, Universidade de Lisboa.

${ }^{3}$ Centro de Educação Física, Universidade Estadual de Londrina.

${ }^{4}$ Faculdade de Ciências do Desporto e Educação Física, Universidade de Coimbra. ${ }^{5}$ Faculdade de Motricidade Humana, Universidade de Lisboa.

\title{
Prevalence of physical activity through the practice of sports among adolescents from Portuguese speaking countries
}

\author{
Prevalência de atividade física através da prática esportiva \\ em adolescentes de países de língua Portuguesa
}

Abstract This study evaluated the prevalence of physical activity through the practice of sports in adolescents from schools in two Brazilian cities and a Portuguese school, and its association with independent variables, such as gender and age. A cross-sectional study was conducted of schoolchildren from two cities in Brazil and one in Portugal. The total study sample was 3694 subjects (1622 males and 1872 females). Physical activity levels were assessed using Baecke's questionnaire. Body weight was measured on electronic scales and stature was measured with a portable wooden stadiometer. Numerical variables were expressed as mean, categorical variables were expressed as percentages and the chi-square test analyzed associations. The prevalence of no sport was high (39.7\%), being higher in the Portuguese school than in the Brazilian schools $(p<0.001)$. Irrespective of being an adolescent in a Brazilian or Portuguese school, boys showed higher engagement in sports practice than girls $(p<0.001)$. In both, differences were identified between adolescents aged 13 to $15(P=0.001)$ and 16 to $17(P$ $=0.001)$. The prevalence of physical inactivity among schoolchildren from two cities in Brazil and a school in Portugal was high, with the girls practicing less sport than the boys and with this imbalance likely to be higher in adolescents.

Key words Sports, Physical activity, Adolescents
Resumo Objetivos: Avaliar a prevalência de atividade física por meio da prática de esportes em adolescentes de escolas de duas cidades brasileiras e jovens de uma escola portuguesa e sua associação com variáveis independentes, como sexo e idade. Métodos: Estudo transversal realizado em escolares de duas cidades do Brasil e em adolescentes de uma escola duma cidade de Portugal. A amostra total do estudo foi de 3.694 indivíduos (1.622 meninos e 1.872 meninas). O nível de atividade física foi avaliado usando o questionário Baecke. O peso corporal foi medido por meio de uma balança eletrônica e a estatura foi medida com um estadiômetro portátil. As variáveis numéricas foram expressas em média, as variáveis categóricas foram expressas em porcentagens e o teste do quiquadrado analisou as associações. Resultados: A prevalência de nenhuma prática esportiva foi elevada (39,7\%), sendo mais elevada em adolescentes de uma escola portuguesa do que adolescentes das escolas brasileiras $(p<0,001)$. Independente de ser adolescente de escola brasileira ou portuguesa, os meninos apresentaram maior adesão à prática esportiva do que meninas ( $p<0,001)$. Em ambos, foram identificadas diferenças entre adolescentes de 13-15 anos $(p=0,001)$ e 16-17 anos ( $p=0,001)$. Conclusões: A prevalência de inatividade física em escolares de duas cidades do Brasil e em uma escola de uma cidade de Portugal foi elevada.

Palavras-chave Esportes, Atividade física, Adolescentes 


\section{Introduction}

Currently, coronary heart disease is responsible for the largest number of deaths worldwide ${ }^{1,2}$ and certain variables (diabetes mellitus, hypercholesterolemia, hypertension, overweight, abdominal obesity and physical inactivity) are indicated as important cardiovascular risk factors ${ }^{3-6}$.

The promotion of physical activity is an important factor in preventing and treating cardiovascular risk in both pediatric and adult populations. However, despite the well-documented effect of physical activity, a large number of studies have reported a low prevalence of adults engaged in physical activity ${ }^{7-9}$. Similarly, physical inactivity is observed in pediatric populations ${ }^{10-12}$ and this pattern constitutes a concern, as unhealthy habits track from childhood to adulthood?

On the other hand, physical activity is a behavioral variable which is affected by social and demographic aspects and therefore it is necessary to take these variables into account when establishing actions to promote physical activity. Thus, comparisons of physical activity practice between developed and developing settings can determine the burden of these social and demographic aspects.

Thus, the objective of this study was to assess the prevalence of physical activity through sports practice in adolescents from schools in two Brazilian cities and adolescents in a school from a Portuguese city and its association with independent variables, such as gender and age.

\section{Methods}

In Portugal, the data collection was carried out in the month of May 2008. All measures were performed by previously trained coaches in a high school located in the metropolitan region of Lisbon, Portugal. Prior to the study, all students with ages ranging from 12 to 18 years were invited to participate and their parents gave written informed consent. In Brazil, adolescents of a similar age range (10-18 years) were interviewed through two school based epidemiological studies which were carried out during the second semester of 2007 and the first semester of 2008 in two medium sized Brazilian cities (Presidente Prudente and Londrina $[170 \mathrm{~km}$ distance between them]).

In Portugal, an epidemiological study was carried out in the city of Sintra $(25 \mathrm{~km}$ far from Lisbon) during 2008. In 2008, Sintra had 7,154 adolescents attended by nine schools and to the development of this study a school was selected by convenience (due its geographical proximity with other two cities). The selected school had $12.1 \%$ of all students of the city $(n=863)$ and, after authorization of the school administrative staff, all students regularly registered in the school were invited to participate. After the field work, an overall of 768 students agreed to participate (432 females and 336 males; participation rate $88.9 \%$ ) and received the authorization of yours parents/legal guardians.

In Presidente Prudente all 36 public and private schools that adolescents attend (11 to 17 years) were considered eligible for the study. In the city, $\sim 30 \%$ of the all schoolchildren attend private schools and, therefore, six schools (four public and two private) were selected through draw and all students aged 11-17 were invited to participate. In Londrina, a sample of elementary school students by the respective municipality cluster sampling process opting for data collection class as a whole was obtained. Londrina was divided into 5 geographical areas: north, south, east, west and central. In each region two schools (one public and one private) were chosen by lot, and these schools were stratified and a number of classes were selected to achieve the proportion of each type of school and region. The total study sample was 3694 subjects (1622 males and 1872 females). All procedures were approved by the ethics committee on human experimentation of the institutions involved.

Physical activity level was assessed using the Baecke's questionnaire ${ }^{13}$, which has been previously validated against doubly labeled water ${ }^{14}$ and the tri-axial accelerometer ${ }^{15}$. The instrument has 16 questions and assesses physical activity in three domains: school, sports and leisure. In our study, leisure-time physical activity was assessed through sports practice, because this kind of activity is common among young people. The adopted outcome was no engagement in sports practice (for those adolescents who were classified as engaged in sports practice, neither the frequency nor previous engagement in sports activities were taken into account).

The ages were assessed and stratified into groups (10-12 years; 13-15 years; 16-17 years). All anthropometric measurements were performed within the school itself. All reviews were barefoot, standing, standing in the center of the scale platform and wearing light clothing. Body weight was measured using electronic scales (to the nearest $0.1 \mathrm{~kg}$ and a maximum capacity of 
$150 \mathrm{~kg}$ ). Stature was measured with a portable wooden stadiometer (to the nearest $0.1 \mathrm{~cm}$ and a maximum extension of $200 \mathrm{~cm}$ ). The body mass index (BMI) was determined by dividing the weight by the height squared. Adolescents remained standing, barefoot, turned his back to the vertical surface of the device and the head positioned in the Frankfurt plane, the upper limbs relaxed next to the trunk, with your palms facing your thighs with your heels together, touching the vertical portion of the stadiometer and distant medial edges. Adolescents were classified as normal weight or overweight according to the criteria proposed by Cole et al. ${ }^{16}$.

\section{Statistics analyses}

Data normality was verified by the Komogorov-Smirnov test. Numerical variables were expressed as mean with a confidence interval of 95\% (95\%CI). A comparison of continuous variables according to the adolescent's gender was performed using the Student's t-test for independent samples. Categorical variables were expressed as percentages and the chi-square test analyzed associations (Yates' correction was used for $2 \times 2$ tables). The statistical significance was set at $\geq 0.05$.

\section{Results}

In the overall sample the number of males was $1622(46.4 \%)$. Boys and girls presented similar ages $(\mathrm{P}=0.298)$, while boys were taller and heavier ( $\mathrm{p}=0.001$ for both). On the other hand, BMI was similar in boys and girls (Table 1). The prevalence of overweight among schoolchildren in two cities in Brazil and a school in a town of Portugal was similar, $22.3 \%$ and $25.9 \%$, respectfully $(\mathrm{p}=0.116)$. Figure 1 shows that the prevalence of no sports practice was high $(39.7 \%)$ whilst being higher in Portugal than Brazil ( $\mathrm{P}=$ 0.001 ).

Independent of adolescents from schools in two Brazilian cities or a Portuguese school (Figure 2), boys presented higher engagement in sports practice than girls ( $\mathrm{P}=0.001$ for comparisons within Brazil and Portugal). Linear trends indicated that lower engagement in sport practice was observed in older adolescents.

Regular engagement in sports practice was higher in boys than girls in all age groups (Figure 3). In Portuguese adolescents, the differences were identified in adolescents of 13-15 years ( $P$
$=0.001)$ and $16-17$ years $(P=0.001)$, but not in adolescents of 10-12 years. Similar patterns were observed in all age groups composed of Brazilian adolescents.

\section{Discussion}

A cross-sectional study in which we observed high physical inactivity among schoolchildren in two cities in Brazil and a school in a town from Portugal. The difference between the Brazilian and Portuguese schoolchildren was significant, with the largest physical inactivity observed in adolescents from a school in a Portuguese town. Other studies have also had the objective of comparing physical activity in adolescents from cities of different countries. Greguol et al. ${ }^{17}$, after comparing the practice of physical activity in adolescents with visual problems in Brazil and Italy found no significant differences for this variable. In a study comparing 20 different countries with a broader age range (18-64 years), Bauman et

Table 1. General characteristics of the adolescents from Portuguese speaking countries.

\begin{tabular}{lrrrrrrr}
\hline & \multicolumn{2}{c}{ Male $(\mathbf{N}=\mathbf{1 6 2 2})$} & & \multicolumn{2}{c}{ Female $(\mathbf{N}=\mathbf{1 8 7 2})$} & \\
\cline { 2 - 3 } \cline { 5 - 6 } & Mean & 95\%CI & & Mean & $\mathbf{9 5 \% C I}$ & P \\
\hline Age (years) & 13.44 & $(13.3-13.5)$ & & 13.49 & $(13.4-13.5)$ & 0.298 \\
Weight $(\mathrm{kg})$ & 54.78 & $(54.1-55.5)$ & & 50.81 & $(50.2-51.3)$ & 0.001 \\
Height $(\mathrm{cm})$ & 162.32 & $(161.7-162.9)$ & & 157.67 & $(157.3-158.1)$ & 0.001 \\
BMI $\left(\mathrm{kg} / \mathrm{m}^{2}\right)$ & 20.58 & $(20.3-20.7)$ & & 20.40 & $(20.2-20.5)$ & 0.174
\end{tabular}

$95 \% \mathrm{CI}=95 \%$ confidence interval.

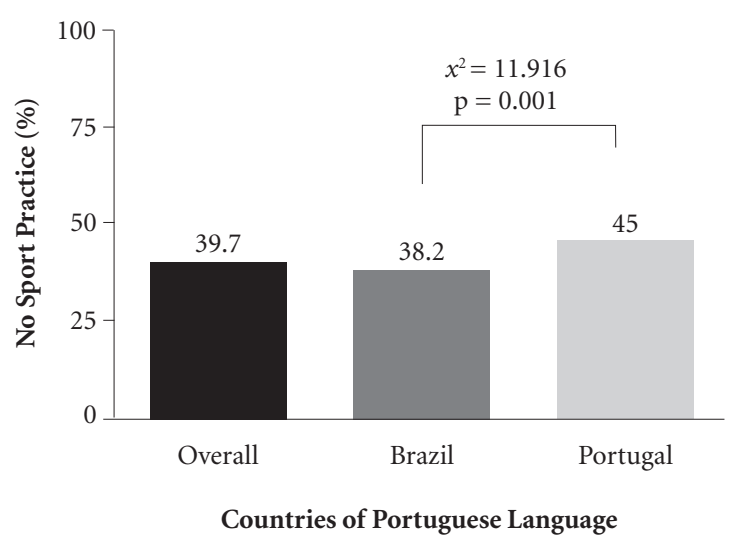

Figure 1. Prevalence of no sports practice in two Portuguese speaking countries. 


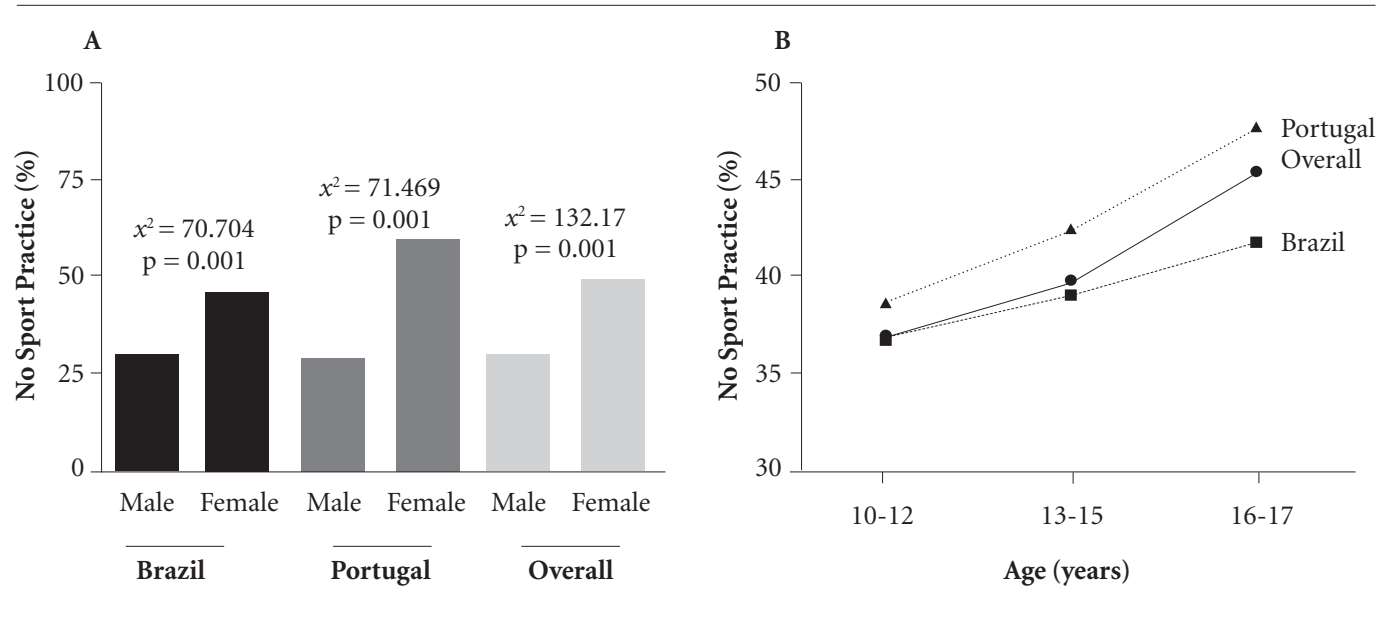

Figure 2. No Sports practice according to sex and age.
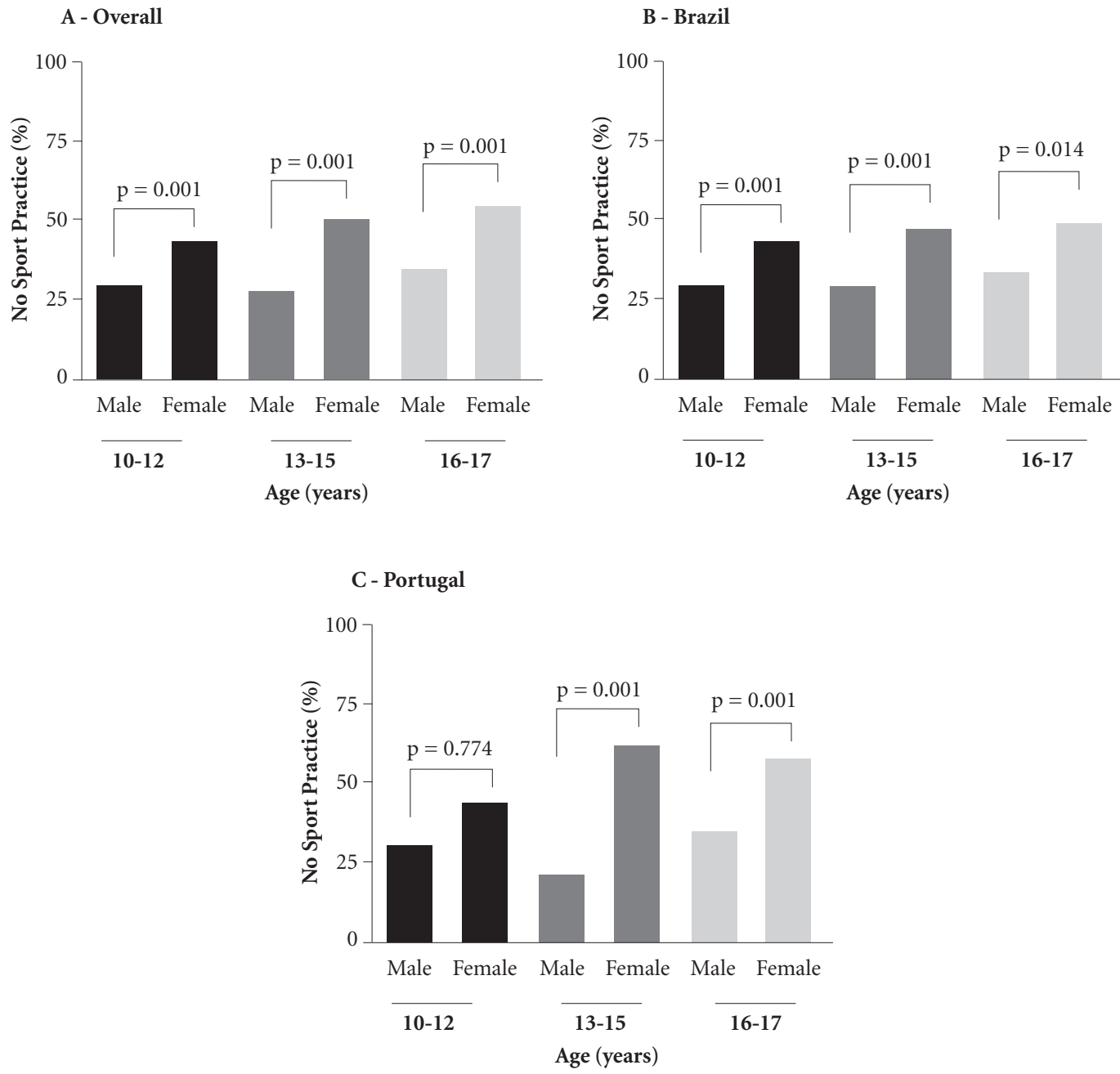

Figure 3. No Sports practice stratified by sex and age. 
al. ${ }^{18}$ observed that there were high differences in physical inactivity among the countries analyzed.

The prevalence of physical inactivity in our study was approximately 40\%. Our results corroborate with other Brazilian research, in which physical inactivity ranged from $39.0 \%{ }^{19}$ to $56.0 \%{ }^{20}$. On the other hand, our values are much higher than the results observed by Sun et al. ${ }^{21}$ who assessed the physical activity in a population of young Japanese from a city in Toyama (only $22.8 \%$ of the boys practiced physical activity seldom or almost never). There are several reasons that may contribute to this discrepancy in the analysis of low physical activity among studies. Methodological factors are a major cause, as using different methodologies to assess physical activity (questionnaires, accelerometers, doubly labeled water) can produce different results.

Even when evaluations are conducted using the same method, for example, questionnaires, there are various forms of coding, the review or not of different domains and several cutoffs. However cultural differences, along with the climate and economic conditions of different countries also have to be considered. In relation to socioeconomic factors, there is no consensus in the literature; these differences could be attributed to the demographic context of the populations studied $^{22}$, in order to find the determinants of prevalence it is necessary to study the characteristics of the population and not confine the investigation to the individual ${ }^{23}$, this is primarily due to the fact that low and middle income countries are undergoing epidemiological transition ${ }^{24,25}$.

Despite the limitations in being able to make comparisons between studies which use different methods for measuring physical activity, one important point is that there seems to be a consensus that girls tend to be more sedentary than boys ${ }^{26-28}$. Gonçalves et al. ${ }^{29}$ also observed the relationship between physical activity and gender. In their study the authors analyzed the physical activity in more than 4,000 adolescents. The girls were considered less physically active than the boys, with a prevalence of $67.5 \%$ and $48.7 \%$, respectively. One possible hypothesis for these findings is that boys have more freedom to explore longer distances from the home, which in turn contributes to increased physical activity, since larger displacement increases energy expenditure. Boys are more physically active with friends outside of school hours, compared to girls ${ }^{29}$, contributing to greater physical activity among these adolescents, especially in team sports such as football, which is often practiced in countries such as
Brazil and Portugal. The boys also seem to receive more encouragement from parents to practice physical activity when compared to girls. One of the factors that may influence this is the relationship that parents have with sports and, considering that the prevalence of being physically active in the adult population is higher in $\operatorname{men}^{7,30}$, this can be a determining factor because of the influence that parents have on male children. Furthermore, social support for physical activity seems to positively influence this behavior ${ }^{31}$.

Another factor observed in this study was the inverse relationship between physical activity levels and age (higher physical inactivity in older adolescents). Corder et al. ${ }^{32}$ in an epidemiological study with an accelerometer found that physical activity tends to decrease with age. Sjostrom et al. ${ }^{33}$ found that approximately $30 \%$ of adolescents from European countries over the age of 15 years were sedentary. In a systematic review, Seabra et al. ${ }^{22}$ found that in most studies physical activity decreased with advancing age.

Possible mechanisms of a biological or behavioral nature could explain this decrease, in a review with nonhumans, Ingram ${ }^{34}$ observed that the reduction in physical activity according to increased age was related to dopamine, since this neurotransmitter is related to adrenalin and noradrenaline, substances stimulating the central nervous system and could contribute in a motivational way to the practice of physical activity. In addition in the move from childhood to adolescence increased responsibilities can arise, since many adolescents begin to work at this time or change their focus to increasing the number of hours they study in order to complete their university education, this reduces their available time which could be associated with the decreased physical activity during this transition. Friendships may also contribute, since at this stage of life seems to be influenced by close friends as to their level of physical activity ${ }^{31,35}$.

This study has some limitations, the cross sectional design avoids causality statements between variables. Another factor is that the analysis of physical activity was assessed by questionnaire rather than a direct method of measurement of physical activity such as an accelerometer or doubly labeled water. We must also mention that all samples are not representative of Portugal and Brazil; therefore, our findings cannot be generalized to the two countries. On the other hand, the strength of our study is that few studies have compared the practice of physical activity in schoolchildren from different nationalities. 
In summary there was a high prevalence of physical inactivity, with the girls practicing less sport than the boys and this imbalance likely to be higher in adolescents aged 16-17 years. This behavior was more pronounced in the schools of two Brazilian cities and a Portuguese school analyzed in the study. Strategies that are conducted in schools and approach the matter with the aim of public health actions to reduce this problem are needed.

\section{Collaborations}

DGD Christofaro, RF Araújo, ERV Ronque, C Martins, MS Coelho, A Silva, L Sardinha and ES Cyrino participated equally in all stages of preparation of the article.

\section{Acknowledgement}

The authors thank the National Council for Scientific and Technological Development (CNPq) for productivity grants in research (ESC and ERVR). 


\section{References}

1. Gray L, Lee IM, Sesso HD, Batty GD. Body weight in early and mid-adulthood in relation to subsequent coronary heart disease mortality: 80-year follow-up in the Harvard Alumni Study. Arch Intern Med 2011; 171(19):1768-1770.

2. Sekikawa A, Kuller LH, Ueshima H, Park JE, Suh I, Jee $\mathrm{SH}$, Lee HK, Pan WH. Coronary heart disease mortality trends in men in the post-World War II birth cohorts aged 35-44 in Japan, South Korea and Taiwan compared with the United States. Int J Epidemiol 1999; 28(6):1044-1049.

3. Babinska I, Veselska ZD, Bobakova D, Pella D, Panico S, Reijneveld SA, Jarcuska P, Jarcuska P, Zezula I, Geckova AM; HEPA-META team. HEPA-META team. Is the cardiovascular risk profile of people living in Roma settlements worse in comparison with the majority population in Slovakia? Int J Public Health 2013; 58(3):417-425.

4. Fernandes J, Lofgren IE. Prevalence of metabolic syndrome and individual criteria in college students. J Am Coll Health 2011; 59(4):313-321.

5. Muraro AP, dos Santos DF, Rodrigues PR, Braga JU. Factors associated with self-reported systemic arterial hypertension according to VIGITEL in 26 Brazilian capitals and the Federal District in 2008. Cien Saude Colet 2013; 18(5):1387-1398.

6. Holme I, Tonstad S. Association of coronary heart disease mortality with risk factors according to length of follow-up and serum cholesterol level in men: the Oslo Study cohort. Eur J Prev Cardiol 2013; 20(1):168-175.

7. Fernandes RA, Zanesco A. Early physical activity promotes lower prevalence of chronic diseases in adulthood. Hypertens Res 2010; 33(9):926-931.

8. Mann KD, Hayes L, Basterfield L, Parker L, Pearce MS. Differing lifecourse associations with sport-, occupational- and household-based physical activity at age 49-51 years: the Newcastle Thousand Families Study. Int J Public Health 2013; 58(1):79-88.

9. Zanchetta LM, Barros MB, César CL, Carandina L, Goldbaum M, Alves MC.Physical inactivity andassociatedfactors in adults, São Paulo, Brazil. Rev Bras Epidemiol 2010; 13(3):387-399.

10. Fernandes RA, Christofaro DG, Dias RM, Codogno JS, Oliveira AR. Malnutrition and its association with activities during leisure time among adolescents. Cien Saude Colet 2014; 19(3):875-880.

11. Knuth AG, Malta DC, Dumith SC, Pereira CA, Morais Neto OL, Temporão JG, Penna G, Hallal PC. Practice of physical activity and sedentarism among Brazilians: results of the National Household Sample Survey-2008. Cien Saude Colet 2011; 16(9):3697-3705.

12. Hidalgo-Rasmussen CA, Ramírez-López G, Hidalgo-San Martín A. Physical activity, sedentary behavior and quality of life in undergraduate adolescents of Ciudad Guzman, State of Jalisco, Mexico. Cien Saude Colet 2013; 18(7):1943-1952.

13. Baecke JA, Burema J, Frijters JE. A short questionnaire for the measurement of habitual physical activity in epidemiological studies. Am J Clin Nutr 1982; 36(5):936942.
14. Philippaerts RM, Westerterp KR, Lefevre J. Doubly labelled water validation of three physical activity questionnaires. Int J Sports Med 1999; 20(5):284-289.

15. Philippaerts RM, Westerterp KR, Lefevre J. Comparison of two questionnaires with a tri-axial accelerometer to assess physical activity patterns. Int J Sports Med 2001; 22(1):34-39.

16. Cole TJ, Bellizzi MC, Flegal KM, Dietz WH. Establishing a standard definition for child overweight and obesity worldwide: international survey. BMJ 2000; 320(7244):1240-1243

17. Greguol M, Gobbi E, Carraro A. Physical activity practice, body image and visual impairment: a comparison between Brazilian and Italian children and adolescents. Res Dev Disabil 2014; 35(1):21-26.

18. Bauman A, Bull F, Chey T, Craig CL, Ainsworth BE, Sallis JF, Bowles HR, Hagstromer M, Sjostrom M, Pratt M; IPS Group. The International Prevalence Study on Physical Activity: results from 20 countries. Int J Behav Nutr Phys Act 2009; 6:21.

19. Oehlschlaeger MH, Pinheiro RT, Horta B, Gelatti C, San'Tana P. Prevalence of sedentarism and its associated factors among urban adolescents. Rev Saude Publica 2004; 38(2):157-163.

20. Hallal PC, Bertoldi AD, Gonçalves H, Victora CG. Prevalence of sedentary lifestyle and associated factors in adolescents 10 to 12 years of age. Cad Saude Publica 2006; 22(6):1277-1287.

21. Sun Y, Sekine M, Kagamimori S. Lifestyle and overweight among Japanese adolescents: the Toyama Birth Cohort Study. J Epidemiol 2009; 19(6):303-310.

22. Seabra AF, Mendonça DM, Thomis MA, Anjos LA, Maia JA. Biological and socio-cultural determinants of physical activity in adolescentes. Cad Saude Publica 2008; 24(4):721-736.

23. Rose G. Sick individuals and sick populations. Int J Epidemiol 1985; 14(1):32-38.

24. Cecchini M, Sassi F, Lauer JA, Lee YY, Guajardo-Barron V, Chisholm D. Tackling of unhealthy diets, physical inactivity, and obesity: health effects and cost-effectiveness. Lancet 2010; 376(9754):1775-1784.

25. Tardido AP, Falcão MC. O impacto da modernização na transição nutricional e obesidade. Rev Bras Nutr Clin 2006; 21(2):117-124.

26. Ceschini FL, Andrade DR, Oliveira LC, Araújo Júnior JF, Matsudo VK. Prevalence of physical inactivity and associated factors among high school students from state's public schools. J Pediatr (Rio J) 2009; 85(4):301306.

27. Christofaro DG, Andrade SM, Fernandes RA, Ohara D, Dias DF, Freitas Júnior IF. Prevalence of risk factors for cardiovascular diseases among students of Londrina PR: Differences between economic classes. Rev Bras Epidemiol 2011; 14(1):27-35.

28. Moraes AC, Fernandes CA, Elias RG, Nakashima AT, Reichert FF, Falcão MC. Prevalence of physical inactivity and associated factors in adolescents. Rev Assoc Med Bras 2009; 55(5):523-528. 
29. Gonçalves H, Hallal PC, Amorim TC, Araújo CL, Menezes AM. Sociocultural factors and physical activity level in early adolescence. Rev Panam Salud Publica 2007; 22(4):246-253.

30. Koohpayehzadeh J, Etemad K, Abbasi M, Meysamie A, Sheikhbahaei S, Asgari F, Noshad S, Hafezi-Nejad N, Rafei A, Mousavizadeh M, Khajeh E, Ebadi M, Nakhjavani M, Esteghamati A. Gender-specific changes in physical activity pattern in Iran: national surveillance of risk factors of non-communicable diseases (20072011). Int J Public Health 2014; 59(2):231-241.

31. Cheng LA, Mendonça G, Farias Júnior JC. Physical activity in adolescents: analysis of the social influence of parents and friends. J Pediatr (Rio J) 2014; 90(1):35-41.

32. Corder K, Sharp SJ, Atkin AJ, Griffin SJ, Jones AP, Ekelund U, van Sluijs EM. Change in objectively measured physical activity during the transition to adolescence. Br J Sports Med. No prelo 2014

33. Sjostrom M, Oja P, Hagstromer M, Smith BJ, Bauman A. Health-enhancing physical activity across European Union countries: the Eurobarometer study. J Public Health 2006; 14(5):291-300.

34. Ingram DK. Age-related decline in physical activity: generalization to nonhumans. Med Sci Sports Exerc 2000; 32(9):1623-1629.

35. Simpkins SD, Schaefer DR, Price CD, Vest AE. Adolescent Friendships, BMI, and Physical Activity: Untangling Selection and Influence Through Longitudinal Social Network Analysis. J Res Adolesc 2013; 23(3):537549.

Article submitted on 26/06/2014

Approved on 21/09/2014

Final version submitted on $04 / 10 / 2014$ 